\title{
Characteristics of the Romanian FOB Exports during the Period 01.01.2016 - 31.10.2016
}

\author{
Wiegand Helmut Fleischer ${ }^{1, *}$ \\ 1"Lucian Blaga" University, Faculty of Engineering, Department for Industrial Engineering and \\ Management, 550024 Sibiu, Romania
}

\begin{abstract}
The aim of this paper is to analyze the Romanian FOB exports during the period 01.01.2016-31.10.2016. My research goal is to identify the most important section of FOB exports during the analyzed period and the main structural modifications in evolution of the Romanian exports. The expected results are to know the most important export section of the Combined Nomenclature, the structural modification in evolution of these industries and the most important partner countries.
\end{abstract}

\section{Introduction}

For a better understanding of the Romanian economy, it is important to analyze the Romanian commercial relations. The characteristics of the Romanian FOB exports will give us important results regarding the main industries and the most important partner countries.

Under the Incoterms 2010 standard published by the International Chamber of Commerce, FOB means "that the seller pays for delivery of goods to the vessel including loading. The seller must also arrange for export clearance. The buyer pays cost of marine freight transportation, insurance, unloading and transportation cost from the arrival port to destination. The buyer arranges for the vessel, and the shipper must load the goods onto the named vessel at the named port of shipment according to the dates stipulated in the contract of sale as informed by the buyer. Risk passes from the seller to the buyer when the goods are loaded aboard the vessel" [13].

The FOB price (free on board price) of exports and imports of goods is "the market value of the goods at the point of uniform valuation, (the customs frontier of the economy from which they are exported). It is equal to the CIF price less the costs of transportation and insurance charges, between the customs frontier of the exporting (importing) country and that of the importing (exporting) country" [14].

\section{Characteristics}

FOB exports during the period 01.01. - 31.10.2016, amounted to 47767.3 million euro and increased with $4.1 \%$ as against the period 01.01 . -31.10 .2015 . [10]

\footnotetext{
* Corresponding author: wiegand.fleischer@ulbsibiu.ro
} 
In the structure of exports, six sections of the Combined Nomenclature hold $71.6 \%$ of total exports, as follows:

Table 1: FOB Exports during the period 01.01. - 31.10.2016 [10]

\begin{tabular}{|c|c|c|c|}
\hline Section of the Combined Nomenclature $(\mathbf{C N})$ & $\begin{array}{c}\text { Value } \\
\text { - million } \\
\text { euro - }\end{array}$ & $\begin{array}{c}\text { Structure in } \\
\text { \% as against } \\
\text { total exports }\end{array}$ & $\begin{array}{c}\text { In \% as } \\
\text { against 01.01.- } \\
\mathbf{3 1 . 1 0 . 2 0 1 5}\end{array}$ \\
\hline $\begin{array}{c}\text { XVI Machinery and mechanical appliances; } \\
\text { electrical equipment; sound and image recorders } \\
\text { and reproducers }\end{array}$ & 14107.6 & 29.5 & 111.3 \\
\hline $\begin{array}{c}\text { XVII Vehicles and associated transport } \\
\text { equipment }\end{array}$ & 8455.7 & 17.7 & 110.2 \\
\hline XV Base metals and articles of base metals & 3729.6 & 7.8 & 93.6 \\
\hline XI Textiles and textiles articles & 3438.2 & 7.2 & 103.2 \\
\hline II Vegetable products & 2783.0 & 5.8 & 109.9 \\
\hline V Mineral products & 1678.8 & 3.5 & 75.0 \\
\hline
\end{tabular}

The main structural modifications came up in the evolution of exports by $\mathrm{CN}$ sections in the period 01.01. - 31.10.2016 as against the period 01.01 - 31.10.2015, consists of:

a) increasing weight for sections: XVI - with 11.3 percentage points, XVII - with 10.2 percentage points and II - with 9.9 percentage points;

b) decreasing weight for sections: $\mathrm{V}$ - with 25.0 percentage points, and XV - with 6.4 percentage points [10].

Exports of section XVI are in an amount of 14107.6 million euro, representing $29.5 \%$ of total exports in the period 01.01. - 31.10.2016, hold the first place and registered an increase of $11.3 \%$ in comparison with the period $01.01-31.10 .2015$.

In this section, the chapters are:

- Chapter "Machinery and mechanical appliances; electrical equipment; sound and image recorders and reproducers" holds 8800.1 million euro exports FOB, representing $62.4 \%$ in total section, $18.4 \%$ in total exports FOB and registered an increase of $10.0 \%$ in comparison with the period 01.01. - 31.10.2015;

- Chapter "Boilers, turbines engines, mechanical apparatus and devices, parts thereof" holds 5307.5 million euro exports FOB, representing $37.6 \%$ in total section and $11.1 \%$ of total exports FOB in the period 01.01. - 31.10.2016 [10].

The second place is held by the exports of section XVII with an amount 8455.7 with $17.7 \%$ in total exports of total exports in the period 01.01. - 31.10.2016 and registered an increase of $10.2 \%$ in comparison with the period $01.01-31.10 .2015$.

In this section, the chapter are:

- Chapter "Vehicles, tractors and other ground vehicles" holds 7376.1 million euro of the exports FOB and represent $87.2 \%$ of total section and $11.1 \%$ of total exports FOB in the period 01.01. - 31.10.2016;

- Chapter "Ships, boats and float structures" holds 760.2 million euro exports FOB, but registered also an increase of $11.4 \%$ in comparison with the period 01.01. - 31.10.2015;

- Chapter "Railway or tramway locomotives and rolling-stock" holds 134.5 million euro exports FOB and registered an increase of $0.2 \%$ in comparison with the period 01.01 . 31.10.2015;

- Chapter "Aircrafts, spacecrafts" holds 184.8 million euro exports FOB and registered an important increase of $11.9 \%$ in comparison with the period 01.01. - 31.10.2015 [10].

Exports of section XV hold the third place as weight in total exports FOB with 3729.6 million euro, registering a decrease of $6.4 \%$ as against the period 01.01. -31.10 .2015 .

In this section, the chapter are:

- Chapter "Products of pig-iron, iron and steel" holds 1348.2 million euro of the exports FOB and registered a decrease of $1.8 \%$ in comparison with the period 01.01. - 31.10.2015; 
- Chapter "Pig-iron, iron and steel" holds 1034.8 million euro exports FOB and registered an important decrease of $2.4 \%$ in comparison with the period 01.01. - 31.10.2015;

- Chapter "Aluminium and articles thereof" holds 769.1 million euro exports FOB and registered a decrease of $8.0 \%$ in comparison with the period 01.01. - 31.10.2015;

- Chapter "Miscellaneous articles of base metal" holds 294.6 million euro exports FOB and registered an increase of $1.0 \%$ in comparison with the period 01.01. - 31.10.2015;

- Chapter "Copper and articles thereof" holds only 165.1 million euro exports FOB, but registered also a decrease of $6.9 \%$ in comparison with the period 01.01. - 31.10.2015;

- Chapter "Tools and implements, cutlery of base metal" holds 70.8 million euro exports FOB and registered a decrease of $2.3 \%$ in comparison with the period 01.01. - 31.10.2015;

- Chapter "Lead and articles thereof" holds 28.4 million euro exports FOB and registered an important increase of $13.8 \%$ in comparison with the period 01.01. - 31.10.2015;

- Chapter "Other base metals; cermets" holds 11.7 million euro exports FOB and registered a decrease of $4.5 \%$ in comparison with the period 01.01. - 31.10.2015;

- Chapter "Zinc and articles thereof" holds 3.3 million euro exports FOB and registered an important decrease of $26.1 \%$ in comparison with the period 01.01. - 31.10.2015;

- Chapter "Tin and articles thereof" holds 1.9 million euro exports FOB and registered an important increase of $17.2 \%$ in comparison with the period 01.01. - 31.10.2015;

- Chapter "Nickel and articles thereof" holds 1.5 million euro exports FOB and registered an important decrease of $43.2 \%$ in comparison with the period 01.01. - 31.10.2015 [10].

Exports of section XI, hold the fourth place as weight in total exports FOB with 3438.2 million euro, registering an increase with $3.2 \%$ as against the period 01.01. - 31.10.2015.

In this section, the chapter are:

- Chapter "Not knitted or crocheted clothing and accessories" holds 1752.3 million euro of the exports FOB and registered an increase of $1.1 \%$ in comparison with the period 01.01.31.10.2015;

- Chapter "Knitted or crocheted clothing and accessories" holds 598.4 million euro exports FOB and registered an increase of $1.1 \%$ in comparison with the period 01.01. - 31.10.2015; - Chapter "Man-made staple fibres" holds 188.4 million euro exports FOB and registered an increase of $3.8 \%$ in comparison with the period 01.01. - 31.10.2015;

- Chapter "Wool, fine or coarse animal hair, horsehair yarn and woven fabric" holds 127.7 million euro exports FOB and registered an increase of $8.7 \%$ in comparison with the period 01.01. - 31.10.2015;

- Chapter "Man-made filaments" holds 114.0 million euro exports FOB and registered an increase of $10.6 \%$ in comparison with the period 01.01. - 31.10.2015;

- Chapter "Impregnates, coated, covered or laminated textile fabrics; technical articles of textiles" holds 74.4 million euro exports FOB and registered an important increase of $0.5 \%$ in comparison with the period 01.01. - 31.10.2015;

- Chapter "Cotton" holds only 56.2 million euro exports FOB, but registered also an important increase of $33.9 \%$ in comparison with the period 01.01. - 31.10.2015;

- Chapter "Knitted or crocheted fabrics" holds 20.3 million euro exports FOB and registered a decrease of $9.6 \%$ in comparison with the period 01.01. - 31.10.2015;

- Chapter "Wadding, felt, special yarns: twine, cords, ropes, articles thereof" holds 46.1 million euro exports FOB and registered an increase of $10.7 \%$ in comparison with the period 01.01. - 31.10.2015;

- Chapter "Other ready-made textile articles" holds 325.1 million euro exports FOB and registered an increase of $8.2 \%$ in comparison with the period 01.01. - 31.10.2015;

- Chapter "Special woven fabrics; tufted textile fabrics; lace, tapestries; trimmings, embroidery" holds 56.3 million euro exports FOB and registered an important increase of $34.6 \%$ in comparison with the period 01.01. -31.10 .2015 ; 
- Chapter "Silk" holds 65.0 million euro exports FOB and registered an important increase of $6.2 \%$ in comparison with the period 01.01. - 31.10.2015;

- Chapter "Carpets and other textile floor coverings" holds 12.7 million euro exports FOB and registered an increase of $1.9 \%$ in comparison with the period 01.01. - 31.10.2015;

- Chapter "Other vegetable textile fibres; paper yarn and woven fabric of paper yarn" holds 1.3 million euro exports FOB and registered an important increase of $37.4 \%$ in comparison with the period 01.01. - 31.10.2015 [10].

Export of section II Vegetable products - hold the fifth place as weight in total exports FOB with 2783.0 million euro, registering an increase of $9.9 \%$ as against the period 01.01 . 31.10.2015.

In this section, the chapter are:

- Chapter "Cereals" holds 1671.4 million euro of the exports FOB and registered an increase of $1.7 \%$ in comparison with the period 01.01.-31.10.2015;

- Chapter "Seeds and fruits; industrial and medicinal plants; straw and fodder" holds 946.5 million euro exports FOB and registered an important increase of $33.5 \%$ in comparison with the period 01.01. - 31.10.2015;

- Chapter "Edible vegetables, roots and tubers" holds 75.7 million euro exports FOB and registered a decrease of $3.2 \%$ in comparison with the period 01.01. - 31.10.2015;

- Chapter "Edible fruits" holds 40.6 million euro exports FOB and registered an important decrease of $37.1 \%$ in comparison with the period 01.01. - 31.10.2015;

- Chapter "Products of the milling industry; malt; starch" holds 22.5 million euro exports FOB and registered an important increase of $31.5 \%$ in comparison with the period 01.01 . 31.10.2015;

- Chapter "Coffee, tea, mate and spices" holds 20.5 million euro exports FOB and registered an important increase of $44.2 \%$ in comparison with the period 01.01 . 31.10.2015;

- Chapter "Live plants, flower products" holds only 2.5 million euro exports FOB, but registered also an important decrease of $23.8 \%$ in comparison with the period 01.01 . 31.10.2015;

- Chapter "Vegetable plaiting materials; vegetable products not elsewhere specified" holds 2.4 million euro exports FOB and registered an important increase of $89.2 \%$ in comparison with the period 01.01. - 31.10.2015;

- Chapter "Lac, gums, resins and other vegetable saps and extracts" holds 1.0 million euro exports FOB and registered a decrease of $29.1 \%$ in comparison with the period 01.01. 31.10.2015 [10].

Table 2: Structure of FOB exports by main groups of goods per month (value in million euro) [1-10]

\begin{tabular}{|c|c|c|c|c|c|c|}
\hline \multirow{7}{*}{ Period } & $\begin{array}{c}\text { XVI Machinery } \\
\text { and mechanical } \\
\text { appliances; } \\
\text { electrical } \\
\text { equipment; } \\
\text { sound and image } \\
\text { recorders and } \\
\text { reproducers }\end{array}$ & $\begin{array}{c}\text { XVII } \\
\text { Vehicles } \\
\text { and } \\
\text { associated } \\
\text { transport } \\
\text { equipment }\end{array}$ & $\begin{array}{c}\text { XV } \\
\text { Base metals } \\
\text { and articles } \\
\text { of base } \\
\text { metals }\end{array}$ & $\begin{array}{c}\text { XI } \\
\text { Textiles } \\
\text { and } \\
\text { textiles } \\
\text { articles }\end{array}$ & $\begin{array}{c}\text { II } \\
\text { Vegetable } \\
\text { products }\end{array}$ & $\begin{array}{c}\text { Vineral } \\
\text { product } \\
\text { s }\end{array}$ \\
\hline 01.2016 & 1240.0 & 690.8 & 338.0 & 320.1 & 193.3 & 164.2 \\
\hline 02.2016 & 1400.6 & 962.2 & 363.7 & 355.9 & 217.0 & 164.6 \\
\hline 03.2016 & 1521.3 & 834.2 & 394.1 & 338.9 & 183.8 & 162.9 \\
\hline 04.2016 & 1395.1 & 879.4 & 373.0 & 362.9 & 138.2 & 170.3 \\
\hline 05.2016 & 1383.9 & 906.2 & 378.4 & 330.5 & 141.3 & 188.1 \\
\hline 06.2016 & 1462.9 & 942.7 & 396.1 & 364.6 & 228.6 & 175.3 \\
\hline
\end{tabular}




\begin{tabular}{|c|c|c|c|c|c|c|}
\hline 07.2016 & 1301.8 & 762.1 & 366.2 & 397.1 & 466.0 & 171.1 \\
\hline 08.2016 & 1309.5 & 692.9 & 330.3 & 286.2 & 415.8 & 169.8 \\
\hline 09.2016 & 1551.1 & 909.0 & 401.2 & 360.4 & 456.8 & 107.2 \\
\hline 10.2016 & 1506.0 & 904.7 & 395.6 & 333.5 & 342.1 & 205.1 \\
\hline$\sum$ & 14107.6 & 8455.7 & 3729.6 & 3438.2 & 2783.0 & 1678.8 \\
\hline
\end{tabular}

Exports of section V Mineral products - hold the sixth place as weight in total exports FOB with 1678.8 million euro, registering an important decrease of $25 \%$ as against the period 01.01. -31.10 .2015 .

In this section, the chapter are:

- Chapter "Mineral fuels and oils; bituminous substances; mineral waxes" holds 1614.2 million euro of the exports FOB and registered an important decrease of $24.8 \%$ in comparison with the period 01.01.-31.10.2015;

- Chapter "Salt; sulphur; stone; plaster; lime and cement" holds 33.8 million euro exports FOB and registered an important decrease of $23.5 \%$ in comparison with the period 01.01. 31.10.2015;

- Chapter "Ores, slag and ash" holds 30.8 million euro exports FOB and registered an important decrease of $34.0 \%$ in comparison with the period 01.01 . -31.10 .2015 [10].

In the period 01.01-31.10.2016, in comparison with the period 01.01. - 31.10.2015, exports to the other 27 European Union (EU28) countries increased with 4.1\%, registering a weight of $71.6 \%$ in total exports [10].

Partner countries holding the first 10 places in the total amount of exports in the period 01.01. -31.10 .2016 (representing $64.7 \%$ of total exports $=$ o. t. e.) were the following:

1. Germany $(21.6 \%$ o. t. e. $)$,

2. Italy (11.7\% o. t. e.),

3. France $(7.1 \%$ o. t. e. $)$,

4. Hungary $(5.2 \%$ o. t. e. $)$,

5. United Kingdom ( $4.4 \%$ o. t. e.),

6. Bulgaria $(3.1 \%$ o. t. e. $)$,

7. Turkey $(3.1 \%$ o. t. e. $)$,

8. Spain $(3.0 \%$ o. t. e. $)$,

9. Poland $(2.9 \%$ o. t. e. $)$,

10. Cehia $(2.6 \%$ o. t. e.). [10].

In the period 01.01. - 31.10.2016, FOB exports amounted to 47767.3 million euro, with $4.1 \%$ more compared with the period 01.01. - 31.10.2015.

\section{Conclusions}

The most important export section of the Combined Nomenclature in the period 01.01.2016 - 31.10.2016 of the Romanian FOB exports are:

- XVI - $29.5 \%$ of total exports;

- $\quad$ XVII - $17.7 \%$ of total exports;

- $\quad \mathrm{XV}-7.8 \%$ of total exports;

- $\mathrm{XI}-7.2 \%$ of total exports;

- $\quad$ II $-5.8 \%$ of total exports;

- $\mathrm{V}-3.5 \%$ of total exports [10].

In order to stabilize the trade balance of Romania, we recommend the increase in exports through better use of the competitive advantages and the focus on the best performing industries of our country [11].

In order to obtain an improvement of the Romanian FOB exports, we recommend following measures: 
1. Improvement of the Romanian infrastructure. Ensuring an infrastructure similar to those of the countries in western Europe (particularly the Bucharest - Nadlac highway) would result in an increase in foreign investments in general, because the poor infrastructure of Romania represents one of the most important impediments to foreign direct investments and creates logistical problems that should not exist if we take into account Romania's favorable geopolitical position;

2. Encouraging the economy through concrete measures to support the investments. Thus, we recommend the preservation of the flat rate tax at the current level or even its decrease by $10 \%$ according to the Bulgarian model.

3. Furthermore, for the investments that involve large capital consumption and provide a higher number of jobs, additional tax incentives should be offered;

4. The adoption of the European Union legislation in Romania is not sufficient; it must be accompanied by detailed application rules designed so that their implementation, their accomplishment should be easy;

5. Ensuring a legislative stability and predictability in Romania, in the sense that regardless of government, there should exist a medium-term strategy related to taxes and the absolutely necessary changes in this area should take effect from 1 January the following years;

6. Focusing on the industries where we would have competitive advantages and which can cope with the European and global competition. The analysis of Romania's exports in the recent years has shown that the production of auto parts and the car production (especially the Dacia brand, part of the Renault group, or Ford) are sectors that can make a significant contribution to balancing the Romanian trade balance [12].

Romania's economy has the potential to grow from year to year and to increase its exports. To realize this important objectives, it is impetuous necessary to improve the efficiency of the production activity and the quality of the Romanian products and services. Thus we have the possibility to reach a balanced and even positive trade balance.

\section{References}

1. Institutul National de Statistica, Buletin Statistic de Comert International, 1/2016, 46-53 (2016)

2. Institutul National de Statistica, Buletin Statistic de Comert International, 2/2016, 46-53 (2016)

3. Institutul National de Statistica, Buletin Statistic de Comert International, 3/2016, 46-53 (2016)

4. Institutul National de Statistica, Buletin Statistic de Comert International, 4/2016, 46-53 (2016)

5. Institutul National de Statistica, Buletin Statistic de Comert International, 5/2016, 46-53 (2016)

6. Institutul National de Statistica, Buletin Statistic de Comert International, 6/2016, 46-53 (2016)

7. Institutul National de Statistica, Buletin Statistic de Comert International, 7/2016, 46-53 (2016)

8. Institutul National de Statistica, Buletin Statistic de Comert International, 8/2016, 46-53 (2016)

9. Institutul National de Statistica, Buletin Statistic de Comert International, 9/2016, 46-53 (2016)

10. Institutul Național de Statistica, Buletin Statistic de Comert International, 10/2016, 46-53 (2016)

11. W.H. Fleischer, Procedia Economics and Finance, 16, 256 (2014)

12. W.H. Fleischer, Relatille economice romano-germane si Uniunea Europeana - Intre controverse si realizari, 283-284, (Editura Alma Mater, Sibiu, 2011)

13. $* * *$ http://en.wikipedia.org/wiki/Incoterms, (2017)

14. $* * *$ https://stats.oecd.org/glossary/detail.asp?ID=1009, (2017) 